\title{
Pharmacokinetic Evaluation of Administration of Losartan with Aspirin in Healthy Volunteers
}

\author{
Mendes GD ${ }^{1,2 *}$, Ferreira PMF ${ }^{4}$, Gagliano-Jucá T ${ }^{5}$, Magalhães JCDA , Santos EM¹, Sampaio M² and De Nucci G $^{3}$ \\ ${ }^{1}$ Department of Surgery, Faculty of Odontology, University Camilo Castelo Branco (UNICASTELO), SP, Brazil \\ ${ }^{2}$ Galeno Research Unit, Latino Coelho St., 1301, Parque Taquaral, 13087-010, Campinas, SP, Brazil \\ ${ }^{3}$ Department of Pharmacology, Faculty of Medical Sciences, State University of Campinas (UNICAMP), Campinas, SP, Brazil \\ ${ }^{4}$ Department of Pharmacology, Institute of Biomedical Sciences, University of Sao Paulo, São Paulo, SP, Brazil \\ ${ }^{5}$ Institute of Biophysics Carlos Chagas Filho/UFRJ, CCS-Bloco G, 21949-900, Rio de Janeiro, RJ, Brazil
}

\begin{abstract}
Losartan and aspirin are often used concomitantly in patients with heart failure, ischemic heart disease and hypertension.

Objectives: To investigate whether aspirin co-administration affects losartan bioavailability.

Methods: 1) Twenty-four healthy volunteers from both sexes were recruited. Volunteers received a single $50 \mathrm{mg}$ losartan with or without a $81 \mathrm{mg}$ aspirin tablet. Blood samples were obtained at $0.25,0.5,0.75,1,1.25,1.5,1.75,2$, $2.33,2.67,3,3.5,4,4.5,5,6,8,10,12$ hour post-dosing. The concentrations of losartan were analyzed by LC-MSMS. Clearance $(\mathrm{Cl})$ and $\mathrm{T}_{1 / 2}$ were used to evaluate a possible drug-drug interaction. $\mathrm{C}_{\max }$ and $\mathrm{AUC}_{0-8}$ were used to evaluate whether co-administration interferes on the bioavailability process.

Results: From the losartan plasma concentrations vs. time curves the following pharmacokinetic parameters were obtained: $\mathrm{ASC}_{0-8}$ hours, $A \cup \mathrm{C}_{\text {inf }}, \mathrm{C}_{\max }, \mathrm{Cl}, \mathrm{Vd}, \mathrm{T}_{\max }, \mathrm{Ke}$ and $\mathrm{T}_{1 / 2}$. No significant differences were observed in $\mathrm{T}_{1 / 2}$ $(p$-value $=0.431), \mathrm{Cl}(p$-value $=0.554), A^{\operatorname{man}} \mathrm{C}_{0-8}$ hours $(p$-value $=0.590), \mathrm{C}_{\max }(\mathrm{p}$-value $=0.987)$ and $\mathrm{Vd}(\mathrm{p}$-value $=$ $0.647)$

Conclusions: Since there is no significant difference in losartan bioavailability and elimination when coadministered with aspirin, we conclude that there is no pharmacokinetic interaction between both drugs. The finding is important since it reassures the safe use of combining AAS to losartan treatment.
\end{abstract}

Keywords: Mass spectrometry - interaction; LC-MS

\section{Introduction}

Losartan is a non-peptide angiotensin II receptor antagonist used as an antihypertensive agent, that block the vasoconstrictor and aldosterone-secreting effects of angiotensin II by type $\mathrm{AT}_{1}$ receptor blockage [1,2]. Losartan may reduce cardiovascular events more significantly than $\beta$-blockers in patients with hypertension and left ventricular hypertrophy [3]. Losartan decreased platelet aggregation by a thromboxane A2-dependent mechanism [4]. The losartan pharmacokinetic parameters after single oral administration of $50 \mathrm{mg}$ to healthy volunteers were between $182-252 \mathrm{ng} / \mathrm{mL}, 0.50-2.66 \mathrm{~h}, 323$ - $480 \mathrm{ng}{ }^{\star} \mathrm{h} / \mathrm{mL}, 1,88-2.84 \mathrm{~h}$ for $\mathrm{C}_{\text {max }}, \mathrm{t}_{\max }, \mathrm{AUC}_{0-\mathrm{e}}, \mathrm{t}_{1 / 2}$, respectively [1,2].

Aspirin (acetylsalicylic acid) is an irreversible inhibitor of the cyclooxygenase (COX)-1 and -2 isoenzymes [5] that is used to reduce arterial thrombosis and primary prevention of myocardial infarction and stroke in low daily dose $(81 \mathrm{mg})$ [6-10]. These effects are explained by decreased production of thromboxane A2 (potent stimulant of platelet aggregation and vasoconstriction), and by adequate production of prostaglandin (vasodilator and platelet inhibitor) with COX-2 activity intact [5]. Low doses of aspirin $(40-50 \mathrm{mg} /$ day) maintain complete blockade of platelet COX-1 [11].

Thus, association of losartan and aspirin is the treatment of hypertension of patients who have risk of developing thromboembolic disease is often observed [12-14]. Aspirin exerts no significant effect on blood pressure in essential hypertensives taking losartan [14-16], however it may attenuate the action of ACE inhibitors by reducing prostaglandin synthesis [15]. Losartan antihypertensive therapy combined with aspirin was more effective than an atenolol- based treatment with aspirin in reducing the primary composite end point of cardiovascular morbidity and mortality [12]. Interestingly, statistical analysis showed interaction between losartan and aspirin [12]. The conclusion was that further studies were needed to clarify a pharmacologic interaction or a selection by aspirin use of patients more likely to respond to losartan treatment [12].

This study is the first pharmacokinetic evaluation between losartan in combination with aspirin. The study aims to compare the pharmacokinetic (absorption and metabolism/elimination process) of single-dose losartan $(50 \mathrm{mg})$ in the presence or absence of aspirin $(81 \mathrm{mg})$ in healthy volunteers to determine whether co-administration affected the pharmacokinetic profiles of the losartan.

\section{Methods}

\section{Pharmacokinetic study}

The study began with 24 volunteers and finished with 21 volunteers.

*Corresponding author: Mendes GD, 415 Jesuíno Marcondes Machado Ave 13092-320, Campinas - SP, Brazil, Tel: + 5519 3251-6928; Fax: + 55193252 1516; E-mail: mendesgd@yahoo.com.br

Received March 08, 2015; Accepted April 03, 2015; Published April 27, 2015

Citation: Mendes GD, Ferreira PMF, Gagliano-Jucá T, Magalhães JCDA, Santos EM, et al. (2015) Pharmacokinetic Evaluation of Administration of Losartan with Aspirin in Healthy Volunteers. J Bioequiv Availab 7: 144-149. doi:10.4172/ jbb.1000229

Copyright: @ 2015 Mendes GD, et al. This is an open-access article distributed under the terms of the Creative Commons Attribution License, which permits unrestricted use, distribution, and reproduction in any medium, provided the original author and source are credited. 
Three volunteers dropped out of the study for personal reasons. The male group was composed of 12 volunteers (32.5 years \pm 8.9 years, mean \pm s.d.m; range 23-52 years), height between 167 and $185 \mathrm{~cm}(174$ $\pm 7 \mathrm{~cm})$, weighing between 66.6 and $82.8 \mathrm{~kg}(76.8 \pm 5.1 \mathrm{~kg})$. The female group was also composed of 12 volunteers ( 27.3 years \pm 9.2 years; range: $18-52$ years), height between 155 and $169 \mathrm{~cm}(163 \pm 5 \mathrm{~cm})$, weighing between 51.0 and $80.0 \mathrm{~kg}(63.5 \pm 9.2 \mathrm{~kg})$.

All subjects gave written informed consent and the State University of Campinas (UNICAMP) ethics committee approved the clinical protocol. All volunteers were healthy as assessed by physical examination, electrocardiogram, and the following laboratory tests: blood glucose, urea, uric acid, creatinine, alkaline phosphatase, aspartase and alanine aminotransferases, gamma-gluthamil transferase, total billirubin, albumin and total protein, trygliceride, total cholesterol, hemoglobin, hematocrit, erythrocyte sedimentation rate, total and differential white cell and platelet counts, and routine urinalysis. All female volunteers were negative on a pregnancy test. All subjects were negative for human deficiency, hepatitis B (except for serological scar) and hepatitis $\mathrm{C}$ virus.

The study was conducted in an open, randomized, 2-period crossover balanced design with a 1-week washout period between doses. During each period, the volunteers were hospitalized at 6:00 p.m. having a normal evening meal, and after an overnight fast starting at 10:00 p.m., they received at 7:00 a.m. a single $50 \mathrm{mg}$ potassic losartan or $50 \mathrm{mg}$ potassic losartan $+81 \mathrm{mg}$ aspirin immediate release tablet. Water $(200 \mathrm{~mL})$ was given immediately after drug administration. Blood samples $(7 \mathrm{~mL})$ from a suitable antecubital vein were collected at $0.25,0.5,0.75,1,1.25,1.5,1.75,2,2.33,2.67,3,3.5,4,4.5,5,6,8,10,12$ hour post-dosing. The blood samples were centrifuged at approximately $2000 \mathrm{x} \mathrm{g}$ for $1 \mathrm{~min}$ at $4^{\circ} \mathrm{C}$, and the decanted plasma stored at $-20^{\circ} \mathrm{C}$ until analysis. All volunteers then fasted for $2 \mathrm{~h}$ following the drug administration, after which a standard breakfast was consumed. A standard lunch and an evening meal were provided $4 \mathrm{~h}$ and $10 \mathrm{~h}$ after dosing, respectively. No other food was permitted during the in-house period. Liquid consumption was permitted ad libitum after lunch but xanthine-containing drinks including tea, coffee, and cola were prohibited. All subjects were requested to stay in the clinical unit for a 12-h period after drug administration.

Systolic and diastolic arterial pressure (measured non-invasively with a sphygmomanometer), heart rate and temperature were recorded just before and at 4,8 and 12 sampling collection.

\section{Formulations}

The following formulations were employed: losartan (Aradois ${ }^{\circledR}$ ) immediate release $50 \mathrm{mg}$ tablets (Biolab Sanus Farmacêutica Ltda., Brazil; lot $\mathrm{N}^{\circ} 2120205$, expiration date 12/2014) and aspirin (Eclasil $\left.{ }^{\circledR}\right)$ $81 \mathrm{mg}$ immediate release tablets (Biolab Sanus Farmacêutica Ltda., Brazil; lot $\mathrm{N}^{\circ}$ 2120071, expiration date 12/2014).

\section{Pharmacokinetics and statistical analysis}

The first-order terminal elimination rate constant (ke) was estimated by linear regression from the points describing the elimination phase on a log-linear plot. Half-life $\left(t_{1 / 2}\right)$ was derived from this rate constant $\left(\mathrm{t}_{1 / 2}=\ln (2) / \mathrm{ke}\right)$. The maximum observed plasma concentration $\left(\mathrm{C}_{\max }\right)$ and the time taken to achieve this concentration $\left(\mathrm{T}_{\max }\right)$ were obtained directly from the curves. The areas under the losartan plasma concentration $v$ s. time curves from 0 -to the last detectable concentration $\left(\mathrm{AUC}_{\text {last }}\right)$ and $v s$. time curves from $0-8 \mathrm{~h}\left(\mathrm{AUC}_{\text {last }}\right)$ were calculated by applying the linear-log trapezoid rule. Extrapolation of these areas to infinity $\left(\mathrm{AUC}_{0 \text {-inf }}\right)$ was done by adding the value $\mathrm{C}_{\mathrm{last}} / \mathrm{ke}$ to the calculated $\mathrm{AUC}_{\text {last }}$ (where $\mathrm{C}_{\text {last }}=$ the last detectable concentration). The clearance $(\mathrm{CL})$ was calculated by Dose/AUC inf $_{\text {last }}$ The volume of distribution $(\mathrm{Vd})$ was calculated by $\mathrm{Cl} / \mathrm{Ke}$. The $\mathrm{T}_{1 / 2}, \mathrm{CL}, \mathrm{ASC}_{0-8 \text { horas }}$ $\mathrm{C}_{\max }$ and $\mathrm{Vd}$ data for the two formulations were analyzed by paired T-Test, as proposed by the US Food and Drug Administration [17-19]. The software used included WinNonlin Professional Network Edition (Pharsight v. 5.3), Microsoft Excel (v. 7.0), GraphPad Prism (v. 3.02) and GraphPad InStat (v. 3.06)

\section{Drug analysis}

The extraction was performed by vortex-mixing $200 \mu \mathrm{L}$ of each plasma sample, placed in glass tubes followed by the I.S. ( $50 \mu \mathrm{L}$ of 2000 $\mathrm{ng} / \mathrm{mL}$ ) and the samples vortex-mixed for $5 \mathrm{~s}$. Formic acid (88\%) was added $(20 \mu \mathrm{L})$ to all tubes and the samples were vortex-mixed for $5 \mathrm{~s}$. Ethyl acetate was then added $(3 \mathrm{~mL})$ to all tubes and performed the extraction by vortex-mixing for $50 \mathrm{~s}$. The samples were centrifuged at $2000 \mathrm{x}$ g for $2 \mathrm{~min}$. The upper organic phase was transferred to another set of clean glass tubes and evaporated until dry under $\mathrm{N}_{2}$ at $50^{\circ} \mathrm{C}$. The dry residues were dissolved with $300 \mu \mathrm{L}$ of acetonitrile/water $(50 / 50$ $\mathrm{v} / \mathrm{v}$ ) by vortex-mixing for $10 \mathrm{~s}$. The solution was transferred to 96 -well plates using automatic pipettes with disposable plastic tips.

\section{Calibration standards and quality control}

Stock solutions of losartan and internal standard (valsartan) were prepared in acetonitrile-water $(50: 50 \mathrm{v} / \mathrm{v})$ at concentrations of $1 \mathrm{mg} /$ $\mathrm{mL}$, respectively. Calibration curves of losartan were prepared by spiking blank plasma at concentrations of 2, 5, 20, 200, 500, 1000, 1500 and $2000 \mathrm{ng} / \mathrm{mL}$ and the analysis was carried out in duplicate for each concentration. The quality control samples were prepared in blank plasma at concentrations of 6, 80, 800 and $1600 \mathrm{ng} / \mathrm{mL}$ (QCA, QCB1, QCB1, and QCC, respectively). The spiked plasma samples (standards and quality controls) were extracted from each analytical batch along with the unknown samples.

\section{Chromatographic conditions}

An aliquot $(10 \mu \mathrm{L})$ of each plasma extract was injected into an Alltech Prevail $\mathrm{C}_{18} 5 \mu \mathrm{m}$ analytical column ( $150 \mathrm{~mm} \times 4.6 \mathrm{~mm}$ i.d.) operating at $50^{\circ} \mathrm{C}$. The compounds were eluted by pumping the mobile phase (acetonitrile and water [70/30; v/v] containing $10 \mathrm{mM}$ formic acid) at a flow rate of $1.2 \mathrm{~mL} / \mathrm{min}$ diluted approximately $1: 12$. Under these conditions, typical standard retention times were $2.0 \mathrm{~min}$ for losartan and $2.7 \mathrm{~min}$ for valsartan, and back-pressure values of approximately 50 Bar were observed. The temperature of the autosampler was kept at $8^{\circ} \mathrm{C}$ and the run-time was $3.75 \mathrm{~min}$.

\section{Mass-spectrometric conditions}

The mass spectrometer (Micromass model Quattro Ultima) was equipped with an electrospray ion source running in positive mode (ES+), was set up in Multiple Reaction Monitoring (MRM) for the transitions $423.30>207.15$, and $436.50>291.00$ for losartan and valsartan, respectively. The dwell time, cone voltage and the collision energy were $0.35 \mathrm{sec}, 15 \mathrm{~V}$ and $22 \mathrm{eV}$ for losartan, $0.35 \mathrm{sec}, 20 \mathrm{~V}$ and 15 $\mathrm{eV}$ for valsartan. Data acquisition and analysis were performed using the software Mass Lynx (v 3.5).

The analysis was conducted and the method was fully validated in accordance with the study protocol and ANVISA (National Health Surveillance Agency) Guidelines for Analytical Methods Validation, including parameters such as sensitivity, specificity, linearity, accuracy, precision and reproducibility. 
Citation: Mendes GD, Ferreira PMF, Gagliano-Jucá T, Magalhães JCDA, Santos EM, et al. (2015) Pharmacokinetic Evaluation of Administration of Losartan with Aspirin in Healthy Volunteers. J Bioequiv Availab 7: 144-149. doi:10.4172/jbb.1000229

The stability of the analytes and internal standard were evaluated in the biological matrix (human plasma) under distinct timing and temperature conditions in two concentrations: 36 days long term at $-20^{\circ} \mathrm{C}, 6: 55$ hours short term at room temperature, 3 freeze and thaw cycles and 70 hours post processing at $8^{\circ} \mathrm{C}$. The stability of the compounds in master solutions was also evaluated. The assessment showed that compounds were stable during the time and conditions of analysis.

\section{Results}

The formulation was well tolerated at the administered doses and no significant adverse reactions were observed or reported. A total of three adverse events were reported during the study, two of them were considered probably related to the administration (vomit [losartan phase] and headache [losartan phase]). The other adverse event was backache [losartan phase]. The biochemical parameters presented no clinically relevant alterations.

No endogenous peak was observed in the mass chromatogram of blank plasma. Figure 1 shows a chromatogram for the standard LOQ sample in which the retention times for losartan and the internal standard was $2.00 \pm 0.3 \mathrm{~min}$ and $2.70 \pm 0.3 \mathrm{~min}$, respectively. The calibration curves (for losartan) showed good linearity $\left(\mathrm{r}^{2}>\right.$ $0,999396)$ within the range 2.00 to $2000 \mathrm{ng} / \mathrm{mL}$ for analyte. The limit of quantification (LOQ), defined as the lowest concentration at which both the precision and accuracy were $<20 \%$, was $12.0 \mathrm{ng} / \mathrm{mL}$. The within- and between-run precision and accuracy for the LOQ and QCs are summarized in Table 1.

Mean pharmacokinetic parameters of losartan obtained from 21 volunteers after administration of losartan $(50 \mathrm{mg})$ in the presence or absence of aspirin $(81 \mathrm{mg})$ are presented in Figure 2 and Table 2. The paired $\mathrm{T}$ test for pharmacokinetic parameters $\left(\mathrm{T}_{1 / 2}, \mathrm{CL}, \mathrm{AUC}_{0-8 \text { horas }}\right.$ $\mathrm{C}_{\max }$ and $\mathrm{Vd}$ ) of losartan after administration of losartan $(50 \mathrm{mg})$ in the presence or absence of aspirin $(81 \mathrm{mg})$ are presented in Table 3.
Blood pressure and heart rate were assessed for 12 hours after administration of losartan $(50 \mathrm{mg})$ in the presence or absence of aspirin (81 mg) (Figure 3).

\section{Discussion}

Several analytical methods were reported in the literature for analysis of losartan in plasma [1]. After the publication of the losartan method quantification in plasmal by our research group, some others groups published new methods for losartan quantification [20-23], but without any improvements. Currently, our method is in the liqliq extraction rather than solid phase extraction used previously [1]. The LC-MS-MS method described here for drug quantification is consistent with the concepts of high sensitivity, specificity and high sample throughput required for pharmacokinetic studies.

\begin{tabular}{|c|c|c|c|c|}
\hline \multicolumn{5}{|c|}{ Intra-Batch Precision and Accuracy $(n=7)$} \\
\hline & & \multicolumn{3}{|c|}{ Losartan } \\
\hline & $\begin{array}{l}\text { Back Conc. } \\
\text { (ng/mL) }\end{array}$ & $\begin{array}{l}\text { Mean Conc. } \\
\text { (ng/mL) }\end{array}$ & Mean CV (\%) & $\begin{array}{c}\text { Mean Accuracy } \\
(\%)\end{array}$ \\
\hline LOQ & 2 & 1.94 & 14.2 & 97.1 \\
\hline QCA & 6 & 5.57 & 3.2 & 92.9 \\
\hline QCB-1 & 80 & 78.1 & 2.4 & 97.6 \\
\hline QCB-2 & 800 & 766 & 1.7 & 95.8 \\
\hline QCC & 1600 & 1560 & 1.7 & 97.2 \\
\hline \multicolumn{5}{|c|}{ Inter-Batch Precision and Accuracy $(n=21)$} \\
\hline & & \multicolumn{3}{|c|}{ Losartan } \\
\hline & $\begin{array}{l}\text { Back Conc. } \\
\text { (ng/mL) }\end{array}$ & $\begin{array}{l}\text { Mean Conc. } \\
\text { (ng/mL) }\end{array}$ & Mean CV (\%) & $\begin{array}{c}\text { Mean Accuracy } \\
(\%)\end{array}$ \\
\hline LOQ & 2 & 1.995 & 12.1 & 99.8 \\
\hline QCA & 6 & 5.714 & 3.6 & 95.2 \\
\hline QCB-1 & 80 & 78.97 & 4.8 & 98.7 \\
\hline QCB-2 & 800 & 781.8 & 2.6 & 97.7 \\
\hline QCC & 1600 & 1618.9 & 6.3 & 101.2 \\
\hline
\end{tabular}

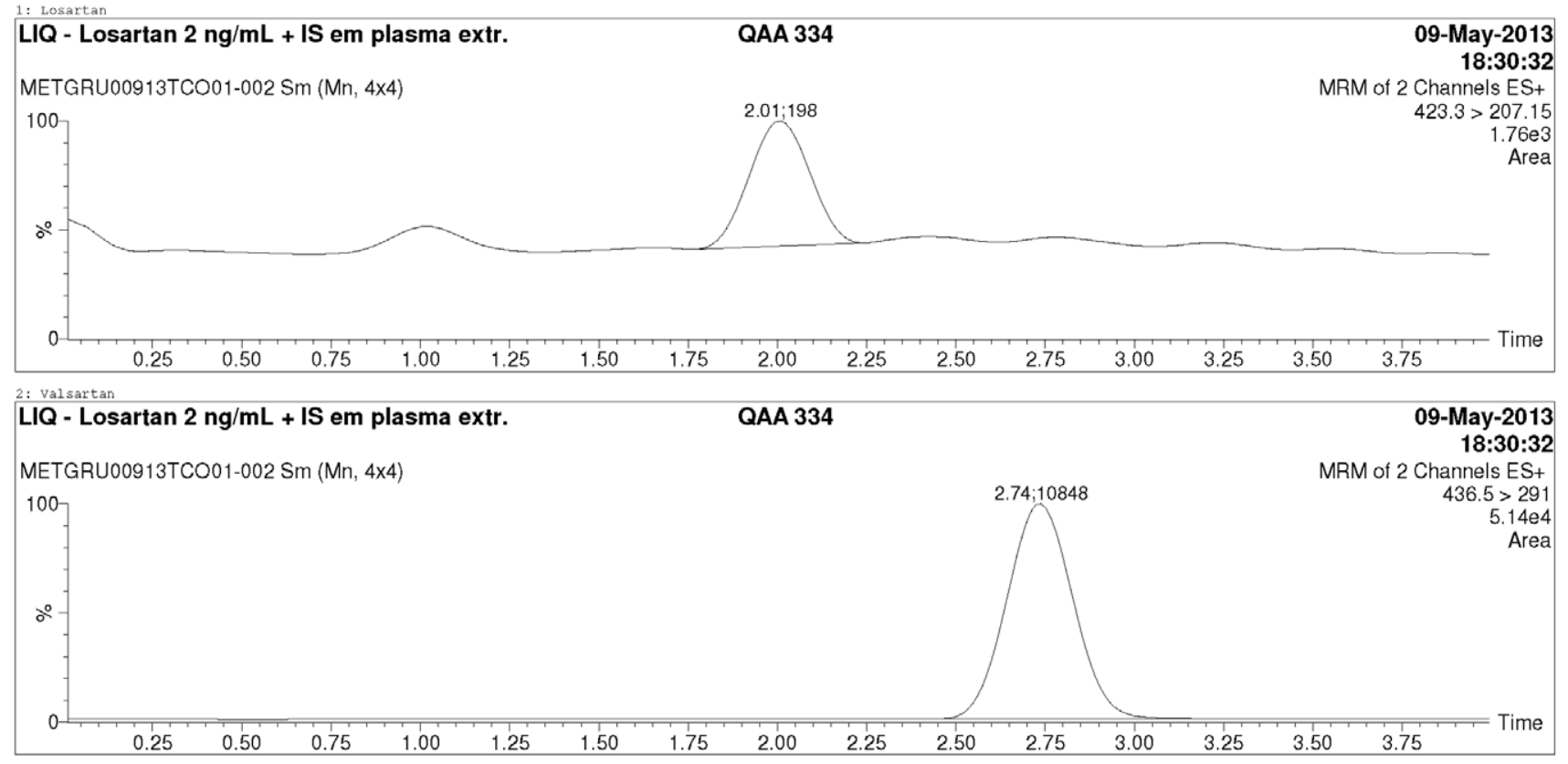

Figure 1: MRM chromatograms of the $L O Q$ sample $(2.0 \mathrm{ng} / \mathrm{mL}):(A)$ losartan and $(B)$ valsartan. 
Citation: Mendes GD, Ferreira PMF, Gagliano-Jucá T, Magalhães JCDA, Santos EM, et al. (2015) Pharmacokinetic Evaluation of Administration of Losartan with Aspirin in Healthy Volunteers. J Bioequiv Availab 7: 144-149. doi:10.4172/jbb.1000229

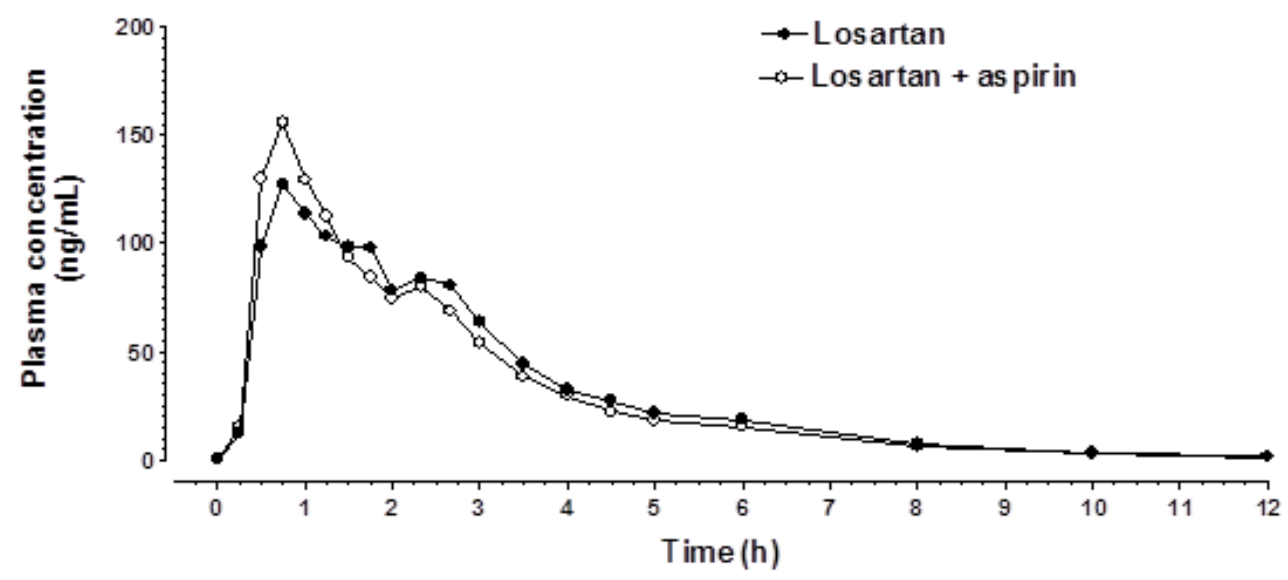

Figure 2: Mean losartan plasma concentrations vs. time curve for losartan after administration of losartan (50 mg) in the presence or absence of aspirin (81 mg) in 21 healthy volunteer.

\begin{tabular}{|c|c|c|c|c|c|c|c|c|}
\hline \multicolumn{9}{|c|}{ Losartan } \\
\hline Variable & Unit & $\mathbf{N}$ & Mean & SD & Min & Median & Max & CV\% \\
\hline AUC \% extrap & $(\%)$ & 21 & 2.46 & 0.98 & 1.07 & 2.06 & 5.15 & 39.77 \\
\hline AUC $_{0-8 h}$ & ([ng*hr]/mL) & 21 & 361.55 & 105.08 & 223.79 & 378.30 & 630.95 & 29.06 \\
\hline AUCinf & ([ng*hr]/mL) & 21 & 382.76 & 112.02 & 239.09 & 403.35 & 665.63 & 29.27 \\
\hline ASC $_{\text {LAST }}$ & ([ng*hr]/mL) & 21 & 373.67 & 110.66 & 231.19 & 395.29 & 655.65 & 29.62 \\
\hline $\mathrm{C}_{\text {LAST }}$ & (ng/mL) & 21 & 2.94 & 0.64 & 2.00 & 3.00 & 4.10 & 21.89 \\
\hline Cmax & (ng/mL) & 21 & 211.05 & 100.61 & 106.00 & 192.00 & 481.00 & 47.67 \\
\hline $\mathrm{Ke}$ & $(1 / \mathrm{hr})$ & 21 & 0.35 & 0.07 & 0.17 & 0.34 & 0.47 & 21.04 \\
\hline $\mathrm{T} 1 / 2$ & (hr) & 21 & 2.10 & 0.58 & 1.47 & 2.01 & 4.08 & 27.63 \\
\hline$T_{\text {LAST }}$ & (hr) & 21 & 10.48 & 1.53 & 8.00 & 10.00 & 12.00 & 14.61 \\
\hline Tmax & (hr) & 21 & 1.03 & 0.71 & 0.50 & 0.75 & 2.67 & 68.81 \\
\hline Vd & (L) & 21 & 417.54 & 122.19 & 241.92 & 401.76 & 678.22 & 29.27 \\
\hline $\mathrm{Cl}$ & (L/h) & 21 & 141.15 & 39.57 & 75.12 & 123.96 & 209.13 & 28.03 \\
\hline \multicolumn{9}{|c|}{ Losartan + Aspirin } \\
\hline Variable & Unit & $\mathbf{N}$ & Mean & SD & Min & Median & Max & CV\% \\
\hline AUC \% extrap & (\%) & 21 & 2.50 & 1.11 & 1.38 & 2.21 & 5.65 & 44.47 \\
\hline $\mathrm{AUC}_{\mathrm{ALL}}$ & ([ng*hr]/mL) & 21 & 384.89 & 143.63 & 196.96 & 366.12 & 761.11 & 37.32 \\
\hline$A C_{0-8 h}$ & ([ng*hr]/mL) & 21 & 369.63 & 138.50 & 194.56 & 353.02 & 731.21 & 37.47 \\
\hline AUCinf & ([ng*hr]/mL) & 21 & 392.43 & 145.82 & 198.89 & 373.46 & 772.54 & 37.16 \\
\hline ASC $_{\text {LAST }}$ & ([ng*hr]/mL) & 21 & 383.30 & 144.41 & 194.56 & 366.12 & 761.11 & 37.67 \\
\hline $\mathrm{C}_{\text {LAST }}$ & (ng/mL) & 21 & 3.12 & 0.87 & 2.00 & 2.80 & 5.40 & 27.91 \\
\hline Cmax & (ng/mL) & 21 & 210.62 & 104.94 & 60.30 & 178.00 & 438.00 & 49.83 \\
\hline $\mathrm{Ke}$ & $(1 / \mathrm{hr})$ & 21 & 0.37 & 0.10 & 0.23 & 0.35 & 0.60 & 26.78 \\
\hline $\mathrm{T} 1 / 2$ & (hr) & 21 & 2.02 & 0.52 & 1.16 & 1.98 & 2.96 & 25.85 \\
\hline $\mathbf{T}_{\text {LAST }}$ & (hr) & 21 & 10.57 & 1.69 & 8.00 & 12.00 & 12.00 & 15.99 \\
\hline Tmax & (hr) & 21 & 1.13 & 0.67 & 0.50 & 0.75 & 2.67 & 59.35 \\
\hline Vd & (L) & 21 & 405.08 & 142.11 & 204.93 & 364.93 & 742.51 & 35.08 \\
\hline $\mathrm{Cl}$ & (L/h) & 21 & 144.72 & 52.76 & 64.72 & 133.88 & 251.40 & 36.46 \\
\hline
\end{tabular}

Table 2: Mean pharmacokinetic parameters of losartan obtained from 21 volunteers after administration of $50 \mathrm{mg}$ losartan in presence or absence of aspirin ( $81 \mathrm{mg}$ ).

Oral administration of losartan and aspirin was considered safe. After oral administration of losartan $(50 \mathrm{mg})$ or losartan $(50 \mathrm{mg})+$ aspirin $(81 \mathrm{mg})$, the observed pharmacokinetic paramenters of losartan of both oral administrations were similar to those reported in the literature for losartan $[1,2]$.

As shown in Figure 3, the systolic and diastolic blood pressures and heart rates measurements revealed no significant alteration after oral administration of losartan $(50 \mathrm{mg})$ or losartan $(50 \mathrm{mg})+$ aspirin
(81 mg), even after 12 hours the administration $(\mathrm{p}=0.1786)$. Indeed no significant change in blood pressure was reported when losartan in addition of either 81 or $325 \mathrm{mg}$ aspirin were administrated [14-16].

For pharmacokinetic interaction between the drugs, it is necessary a significant change in the absorption process or in the process of metabolism / elimination. The area under the curve (AUC) until 08 hours after the administration reflects more accurately the amount of drug absorbed, since after this time the dosage form is in the 
Citation: Mendes GD, Ferreira PMF, Gagliano-Jucá T, Magalhães JCDA, Santos EM, et al. (2015) Pharmacokinetic Evaluation of Administration of Losartan with Aspirin in Healthy Volunteers. J Bioequiv Availab 7: 144-149. doi:10.4172/jbb.1000229

\begin{tabular}{|c|c|c|c|}
\hline \multicolumn{2}{|c|}{$\begin{array}{c}\text { Paired t Test } \\
\mathrm{N}=21\end{array}$} \\
\hline & $P$ value & Mean difference & -0.3118 to 0.1385 \\
\hline$T_{1 / 2}$ & 0.4315 & -0.08667 & -8.835 to 15.982 \\
\hline$C_{L}$ & 0.5547 & 3.574 & -22.746 to 38.910 \\
\hline CUC $_{8 \text { horas }}$ & 0.5905 & $\mathbf{8 . 0 8 2}$ & -57.370 to 56.522 \\
\hline$C_{\text {max }}$ & 0.9878 & -0.4238 & -68.381 to 43.467 \\
\hline
\end{tabular}

Table 3: Paired $\mathrm{T}$ test for $\mathrm{T}_{1 / 2}, \mathrm{CL}, \mathrm{AUC}_{0-8 \text { horas, }} \mathrm{Cmax}$ and $\mathrm{Vd}$ after administration of $50 \mathrm{mg}$ losartan in presence or absence of aspirin (81 mg).

Enect on blood pressure of los artan

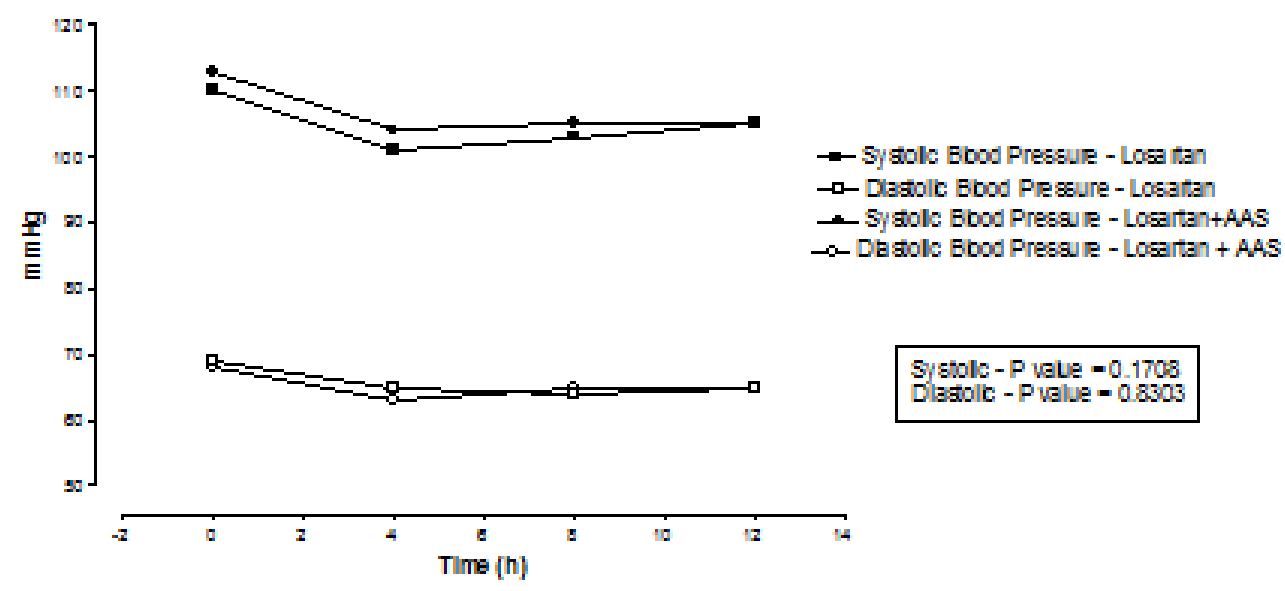

Nean heart rate

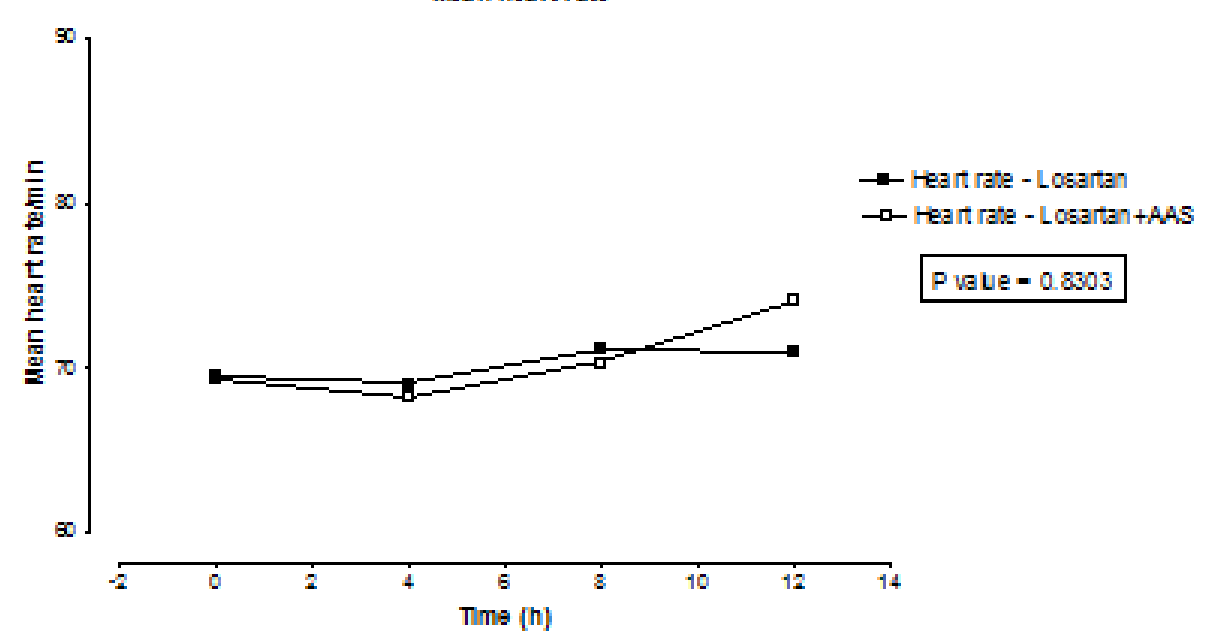

Figure 3: Mean sitting systolic and diastolic blood pressures and sitting heart rates of losartan (50 mg) in the presence or absence of aspirin ( $81 \mathrm{mg})$ in 21 healthy volunteer.

large intestine where drug absorption does not occur. The process of metabolism-elimination is responsible for clearance of the drug, which determines the half-life of the drug [23].

More studies were needed to clarify a pharmacologic interaction or a selection by aspirin use of patients more likely to respond to losartan treatment [12]. As noted in the Table 3, there is no significant difference in the area under the curve (AUC) until 8 hours of losartan, as there is no significant difference in the parameter for the clearance (clearance itself, and the half-life). The statistical test used was the paired t test considered by the FDA $[18,19]$ as a test sensitive for identification of pharmacokinetic interactions (in others words, carries the risk of detecting pharmacokinetic interactions that are not clinically relevant).

\section{Conclusion}

Since there is no significant difference in losartan bioavailability and elimination when co-administered with aspirin, we conclude 
Citation: Mendes GD, Ferreira PMF, Gagliano-Jucá T, Magalhães JCDA, Santos EM, et al. (2015) Pharmacokinetic Evaluation of Administration of Losartan with Aspirin in Healthy Volunteers. J Bioequiv Availab 7: 144-149. doi:10.4172/jbb.1000229

that there is no pharmacokinetic interaction between both drugs. The finding is important since it reassures the safe use of combining AAS to losartan treatment.

\section{Acknowledgements}

This comparative bioavailability trial was funded by Biolab Sanus Farmacêutica Ltda. Jim Hesson of AcademicEnglishSolutions.com revised the English.

\section{References}

1. Oliveira $\mathrm{CH}$, Medeiros Silva R, Santagada V, Caliendo G, Perissutti E, et al. (2006) Comparative bioavailability of two losartan formulations in healthy human volunteers after a single dose administration. Int J Clin Pharmacol Ther 44: 142-148.

2. Tamimi JJ, Salem II, Mahmood Alam S, Zaman Q, Dham R (2005) Comparative pharmacokinetics of two tablet formulations of Losartan: bioequivalence assessment. Biopharm Drug Dispos 26: 205-210.

3. Zaiken K, Hudd TR, Cheng JW (2013) A review of the use of angiotensin receptor blockers for the prevention of cardiovascular events in patients with essential hypertension without compelling indications. Ann Pharmacother 47 686-693.

4. Guerra-Cuesta JI, Montón M, Rodríguez-Feo JA, Jiménez AM, González Fernández $\mathrm{F}$, et al. (1999) Effect of losartan on human platelet activation. J Hypertens 17: 447-452.

5. Nemerovski CW, Salinitri FD, Morbitzer KA, Moser LR (2012) Aspirin for primary prevention of cardiovascular disease events. Pharmacotherapy 32: 1020-1035.

6. Wolff T, Miller T, Ko S (2009) Aspirin for the primary prevention of cardiovascula events: an update of the evidence for the U.S. Preventive Services Task Force. Ann Intern Med 150: 405-410.

7. Kolber M, Sharif N, Marceau R, Szafran O (2013) Family practice patients use of acetylsalicylic acid for cardiovascular disease prevention. Can Fam Physician 59: 55-61.

8. Zhang Y, Neogi T, Chen C, Chaisson C, Hunter DJ, et al. (2014) Low-dose aspirin use and recurrent gout attacks. Ann Rheum Dis 73: 385-390.

9. Mainous AG, Tanner RJ, Shorr RI, Limacher MC (2014) Use of aspirin for primary and secondary cardiovascular disease prevention in the United States, 2011-2012. J Am Heart Assoc 3.

10. Pearson TA, Blair SN, Daniels SR, Eckel RH, Fair JM, et al. (2002) AHA Guidelines for Primary Prevention of Cardiovascular Disease and Stroke: 2002 Update: Consensus Panel Guide to Comprehensive Risk Reduction for Adult Patients Without Coronary or Other Atherosclerotic Vascular Diseases. American Heart Association Science Advisory and Coordinating Committee. Circulation 106: 388-391.

11. Loprete L, Leuratti C, Scarsi C, Radicioni M (2014) Pharmacodynamics and pharmacokinetics of a novel, low-dose, soft-gel capsule of acetylsalicylic acid in comparison with an oral solution after single-dose administration to healthy volunteers: a phase I, two-way crossover study. Clin Drug Investig 34: 19-25.

12. Fossum E, Moan A, Kjeldsen SE, Devereux RB, Julius S, et al. (2005) The effect of losartan versus atenolol on cardiovascular morbidity and mortality in patients with hypertension taking aspirin: the Losartan Intervention for Endpoint Reduction in hypertension (LIFE) study. J Am Coll Cardiol 46: 770-775.

13. Gibbons RJ, Abrams J, Chatterjee K, Daley J, Deedwania PC, et al. (2003) American College of Cardiology; American Heart Association Task Force on practice guidelines (Committee on the Management of Patients With Chronic Stable Angina). ACC/AHA 2002 guideline update for the management of patients with chronic stable angina--summary article: a report of the American College of Cardiology/American Heart Association Task Force on practice guidelines. J Am Coll Cardiol 41: 159-168.

14. Ujiie Y, Hirosaka A, Mitsugi M, Ohwada T, Igarashi M, et al. (2006) Effects of angiotensin-converting enzyme inhibitors or an angiotensin receptor blocker in combination with aspirin and cilostazol on in-stent restenosis. Int Heart J 47: 173-184.

15. Nawarskas JJ, Townsend RR, Cirigliano MD, Spinler SA (1999) Effect of aspirin on blood pressure in hypertensive patients taking enalapril or losartan Am J Hypertens 12: 784-789.

16. Frey MJ, Healy M, Klinger G, Toh J, Rucinska E (1996) Effect of aspirin on the acute and chronic hemodynamic response to angiotensin II receptor blockade with losartan in heart failure. J Am Coll Cardiol 27: 228-228.

17. Iyer SN, Yamada K, Diz DI, Ferrario CM, Chappell MC (2000) Evidence that prostaglandins mediate the antihypertensive actions of angiotensin-(1-7) during chronic blockade of the renin-angiotensin system. J Cardiovasc Pharmacol 36: 109-117.

18. (2006) Drug Interaction Studies - Study Design, Data Analysis, and Implications for Dosing and Labeling - FDA

19. (2012) Drug Interaction Studies - Study Design, Data Analysis, and Implications for Dosing and Labeling - FDA

20. Harrison P, Mackie I, Mumford A, Briggs C, Liesner R, et al. (2011) Guidelines for the laboratory investigation of heritable disorders of platelet function. $\mathrm{Br} \mathrm{J}$ Haematol 155: 30-44.

21. Prasaja B, Sasongko L, Harahap Y, Hardiyanti, Lusthom W, et al. (2009) Simultaneous quantification of losartan and active metabolite in human plasma by liquid chromatography-tandem mass spectrometry using valsartan as internal standard. J Pharm Biomed Anal 49: 862-867.

22. Rao RN, Raju SS, Vali RM, Sankar GG (2012) Liquid chromatography-mass spectrometric determination of losartan and its active metabolite on dried blood spots. J Chromatogr B Analyt Technol Biomed Life Sci 902: 47-54.

23. Kyrklund C, Backman JT, Neuvonen M, Neuvonen PJ (2003) Gemfibrozi increases plasma pravastatin concentrations and reduces pravastatin renal clearance. Clin Pharmacol Ther 73: 538-544. 